\title{
SOME NEW OR LITTLE KNOWN SOUTHERN SPIDERS
}

\author{
By Elizabeth B. Bryant \\ Museum of Comparative Zoölogy
}

At the Museum of Comparative Zoölogy within the last two years many spiders have been received from Mr. George Nelson that were collected in Alabama and Florida. Among them were found the following species that are either new or known only from one sex. All are in the museum collection.

\section{FAMILy OONOPIDAE}

Genus Philesius Simon 1893

Philesius vernalis spec. nov.

Female. Length, $1.6 \mathrm{~mm}$., ceph. $0.4 \mathrm{~mm}$., abd. $1.2 \mathrm{~mm}$.

Cephalothorax bright brown, moderately convex, slightly granulate with a minute hair from each pit, anterior margin less than half the greatest width; eyes, a.l.e. largest of the six, separated by less than a radius, posterior row about the same length as the anterior row, straight, p.m.e. surrounded by black, a very broad oval, touching on the long diameter and separated from p.l.e. by about a line, p.l.e. smaller than p.m.e.; clypeus less than a diameter of a.l.e.; labium triangular, almost as long as broad; maxilla inclined over labium, tips almost touching; sternum triangular, about two-thirds as wide as long, truncate between IV coxæ, all coxæ globose; abdomen pale, elliptical, half as wide as long, four-fifths of dorsum covered by an orange colored scutum, punctate, with a minute hair from each pit, venter with an orange colored scutum, that covers the basal two-thirds, also punctate with a hair from each pit, spinnerets closely grouped and not surrounded by a chitinous ring; legs paler than cephalothorax, no spines and very few hairs; epigynum, area swollen but showing no structure.

Holotype, + Florida; Sebastian, March 1944, (Nelson).

The genus Philesius was based by Simon on a single species known from both male and female from St. Vincent. Philesius marmoratus the genotype, is much larger than $P$. vernalis. The genus is separated from Gamasomorpha which is widely dis- 
tributed, by the ventral scutum shorter than the dorsal, and no chitinous ring about the spinnerets.

Family Pisaurid $a$ e

Genus Thanatidius Simon 1898

Thanatidius tenuis (Hentz)

Figures 1, 6

Thomisus ? tenuis Hentz, 1847, p. 449, pl. 23, fig. 12; reprint, 1875, p. 82, pl. 10, fig. 12. "q Alabama."

Thanatidius tenuis Bishop, 1924, p. 18.

Male. Length, $14.6 \mathrm{~mm}$., ceph. $5.5 \mathrm{~mm}$. long, $4.0 \mathrm{~mm}$. wide, an. margin, $2.0 \mathrm{~mm}$., abd. $10.2 \mathrm{~mm}$. long, $2.5 \mathrm{~mm}$. wide at base, I leg. $42 \mathrm{~mm}$. long.

Cephalothorax pale yellow, with a pair of narrow parallel darker stripes from p.m.e. to posterior margin, sparsely covered with short hairs, flat, thoracic groove very long and shallow, sides rounded and abruptly narrowed at region of posterior eye row to half the greatest width, an oblique row of bristles between lateral eyes and margin; eyes apparently in four rows, anterior row strongly procurved, eyes subequal, a.m.e. separated by slightly more than a diameter and from a.l.e. by fully two diameters, posterior row strongly recurved, slightly longer than anterior row, p.m.e. subequal with a.m.e., separated by fully two diameters, p.l.e. largest of the eight, slightly raised and directed backward, lateral eyes separated by about as much space as between p.l.e.; quadrangle of median eyes higher than wide and wider behind than in front; clypeus below a.l.e. less than a radius of a.l.e., a row of long bristles on margin of clypeus; mandibles vertical, pale, few long bristles near median margin, fang groove rather short, lower margin with three subequal teeth; labium white, longer than wide; maxilloe white, fully twice as long as labium, sides parallel; sternum white, flat, almost as wide as long, $(4.0: 4.5)$, with a few short bristles; abdomen a pale reddish-brown, very narrow, ending in a point above spinnerets, base bilobed, on sides a few dark dots, each bearing a short bristle, venter pale; legs, 1-2-4-3, all very long and slender; spines, I pair, patella, lateral, 2, tibia, ventral, $2-2-2-2-2$, apical pair short, metatarsus, ventral, $2-2-2-2$, all spines very long but not overlapping as in female; palpus, pale, not as long as cephalothorax, tibia longer than patella, but tibia 
plus patella not as long as femur, tibia and patella each with a long dorsal spine, tibial apophysis very near distal end, a black, thin leaf-like projection, best seen in a lateral view, palpal organ very similar to Thanatidius dubius (Hentz), figured by Bishop and Crosby, 1936.

Allotype, ô Alabama; Silver Hill, July 1945, (Nelson); Additional specimens, \& Alabama; Silver Hill, July 1945, (Nelson); î Alabama; Silver Hill, June 1945, (Krob).

The genus was based by Simon on Thomisus ? dubius Hentz and Thomisus ? tenuis Hentz, but as Bishop noted in 1924, unfortunately, Simon had a specimen of Tetragonophthalma undulata Keyserling instead of either of the two Hentz species. Bishop also erred in the number of ventral spines on the first and second tibiæ. There are five pairs of ventral spines with the apical pair very short. In the female, the spines are long and over-lapping but in the male, the legs are so much longer that the spines do not over-lap. In 1924, Bishop in the revision of the Pisauridæ described females of Thanatidius tenuis from Georgia, Florida and Louisiana.

Family Oxyopides

Genus Oxyopes Latreille 1804

Oxyopes nelsoni spec. nov.

Figures 5, 7

Male. Length, $5.0 \mathrm{~mm}$., ceph. $2.4 \mathrm{~mm}$. long, $1.6 \mathrm{~mm}$. wide, abd. $2.5 \mathrm{~mm}$. long.

Cephalothorax yellowish, with wide slightly converging lateral dark stripes from p.l.e. to posterior margin, median area with vague dark marks, eyes surrounded by wide black rings, clypeus black, cephalothorax very high, widest between third coxæ, gradually narrowed anteriorly, thoracic groove long and faint, thoracic portion falls abruptly from groove; eyes, anterior row strongly recurved, a.m.e. very small, separated by a diameter, a.l.e. about twice the diameter of a.m.e. and separated from them by more than two diameters, posterior row longer than anterior, strongly procurved, eyes subequal and equidistant; quadrangle formed by a.l.e. and p.m.e. slightly wider in front and higher than wide; clypeus not as high as quadrangle of median eyes, slightly convex; mandibles dark, vertical, cone-shaped, fang groove very short; labium brown at tip, 
longer than wide; maxillae one and a half times as long as labium, outer half black, narrow; sternum pale, with vague elongate dark marks opposite coxæ, nearly as wide as long, $(3.0: 3.5)$, ending in a sharp point between fourth coxæ; abdomen almost black with middle area paler, widest at base and tapering to width of spinnerets at tip, venter black; legs pale with a narrow ventral black stripe on femora, posterior femora with a ventral line of black dots parallel to black line, spines long and black, few trichobothria on ventral surface of femora near base; palpus black, not as long as cephalothorax, tibia slightly longer than patella, with a very large spatulate process with two small marginal chitinized teeth near base on ventral side, no chitinized lobe on base of cymbium to interlock with tibial process, cymbium covered with black hairs, almost as wide as long, (4:5), ending in a very slender tip.

Female. Length, $6.0 \mathrm{~mm}$., ceph. $2.5 \mathrm{~mm}$. long, $1.6 \mathrm{~mm}$. wide, abd. $2.8 \mathrm{~mm}$. long.

Cephalothorax same as in male, but clypeus pale with two dark lines from a.m.e. that continues the length of the mandibles; eyes same as in male but surrounding black rings narrower and area between eyes covered with short white hairs; abdomen with a wide median pale stripe, sides black, venter pale with two parallel dark stripes; legs same as in male, trichobothria very prominent on ventral surface of femora near base; epigynum with a wide hairy median lobe, with a rounded tip that does not reach fold, each side are chitinized areas which partly surround the transverse openings, anterior to openings but below surface are dark sacs.

Holotype, \& Florida; Sebastian, 1-8 April 1944, (Nelson).

Allotype, of Florida; Sebastian, 1-8 April 1944, (Nelson). Paratype, of Florida; Sebastian, 1-8 April 1944, (Nelson). In 1902, F. O. P.-Cambridge described in the Biol. Centr.Amer., vol. 2, p. 344, Oxyopes tibialis from Guatemala. The description is very brief and the clypeus is described with "fine black line on each side that crossing the clypeus and running down the mandibles, and a narrow black line running down the anterior side of the femora of all four pairs of legs." The tibia of the palpus is figured with "a long conspicuous process beneath it, strongly and concavospatulate at the apex." The female of Oxyopes nelsoni has the black lines on the clypeus and mandibles, and the black lines on the femora but the tibial 
process on the male palpus is much larger than is figured for $O$. tibialis and has two small teeth near the base and lacks the process on the cymbium.

Through the courtesy of Dr. H. Dietrich of Cornell University, I have been able to examine the holotype female and the allotype male of Oxyopes aglossus Chamberlin from Billy's Island, Okefenokee Swamp, Georgia, collected by Dr. C. R. Crosby, June 1912. Figures $(8,10)$ are now given for comparison of the epigynum and palpus of this species. Both differ from $O$. nelsoni. The epigynum of $O$. aglossus is very distinct. The median lobe has a truncate tip and below is a darkened transverse band that apparently connects the two sacs beneath the surface. The tibial apophysis of the male palpus does not project at right angles as far from the tibia as is shown in the original figure and on the ventral side there is a rather slender branch with an anterior tooth that is set at right angles to the tibia. The original figure was from the dorsal side and shows only the process and the interlocking process on the cymbium. It is not impossible that the figure was drawn from another specimen and may be another species.

\section{FAMIly TheridiId $A$ e}

Genus Emertonella gen. nov.

Cephalothorax low and flat, as wide as long, thoracic groove very short; eyes, both rows recurved, a.m.e. largest of the eight, lateral eyes touching; quadrangle of median eyes wider than long; clypeus higher than quadrangle; mandibles vertical and weak; labium wider than long; sternum as wide as long, prolonged between fourth coxæ in a truncate lobe; abdomen oval, dorsum thickened, venter with a large epigastric scutum that surrounds the pedicel and a large infra-mammillary scutum, both can be seen from dorsal side; legs, 4-1-2-3, differing little in length; palpus with a short straight embolus, parallel to the conductor. Female unknown.

Genotype: Emertonella emertoni (Bryant).

The genus Emertonella differs from the genus Histagonia Simon, 1894, by the sternum extending between the posterior coxæ, by a faint dorsal scutum and the well defined scutum around and anterior to the spinnerets; from the genus Paidisca Bishop and Crosby, 1926, by the faint dorsal scutum, by a large 
ventral scutum that includes the spinnerets and the absence of a stridulating organ between the abdomen and the cephalothorax.

\section{Emertonella emertoni (Bryant)}

Euryopis emertoni Bryant, 1933, p. 1, fig. 1. " ô Georgia; Thompson's Mills, (Allard), Banks Coll."

Euryopis spinigera Emerton, 1924, p. 143, figs. 4, a-d nec Euryopis spinigera O. P.-Cambridge, 1895, p. 146, pl. 19, fig. 2.

Male. Length, $1.8 \mathrm{~mm}$., ceph. $0.7 \mathrm{~mm}$., abd. $1.1 \mathrm{~mm}$.

Cephalothorax low and flat, as wide as long, anterior margin very little narrowed, thoracic groove short, a group of short erect hairs arranged in a diamond pattern anterior to the groove; eyes heavily ringed with black, cover anterior margin, anterior row recurved, a.m.e. convex, largest of the eight, separated by less than a diameter, almost touching a.l.e., posterior row very slightly recurved, lateral eyes touching, p.m.e. separated by about a diameter and from p.l.e. by a radius; quadrangle wider than long, wider in front than behind; clypeus higher than quadrangle; mandibles vertical and weak; labium wider than long; maxillce twice as long as labium and inclined; sternum pale, as wide as long, convex, tip prolonged between coxæ as a truncate lobe; a row of hairs about margin directed inward; abdomen pale gray, the color ending abruptly on the sides, oval, more than half as wide as long, (5.0:7.0), with many long stiff hairs, each from a dark granule, two pairs of muscle spots, venter almost covered by an epigastric and inframammillary scuta, the anterior margin of the former can be seen on the dorsum and extends to the middle of the venter, the inframammillary scutum almost reaches the middle of the venter and dorsally covers the constricted tip of the abdomen, several small chitinized spots on sides and between the two large ventral scuta, posterior half of the venter with numerous long hairs, each from a pit, hairs not as long as those on the dorsum; legs, 4-1-2-3, pale, with distal joints darker, no spines and few hairs, a tarsal comb on IV tarsus of six stiff bristles; palpus not as long as cephalothorax, pale, with terminal joint much darker, patella and tibia short and broad, terminal joint broad, embolus at tip, a short straight spine, parallel to the large conductor.

This species was briefly described and figured by J. H. Emerton in 1924, as Euryopis spinigera O. P.-Cambridge, 1895. 
Emerton examined three specimens, all males from widely separated localities, Chatham, Massachusetts, Charleston, South Carolina, and Riverhead, Long Island, New York. The first two specimens are in the Emerton Collection and the last in the C. I. Crosby Collection at Ithaca. Within a few years, the species has been found in Alabama and Oklahoma. A careful examination shows several characters that were not mentioned in the Emerton description.

Emertonella emertoni differs from the genus Euryopis by the very short thoracic groove, the two large ventral scuta, the numerous long stiff hairs on the dorsum. The two pairs of muscle spots on the dorsum are very conspicuous in this species.

Family Argiopid $\approx$

Genus Theridiosoma O. P.-Cambridge 1879

Theridiosoma nelsoni spec. nov.

Figure 4

Female. Length, $1.5 \mathrm{~mm}$., ceph. $0.6 \mathrm{~mm}$., abd. $1.0 \mathrm{~mm}$.

Cephalothorax pale, head high; eyes about cover anterior margin, each eye heavily ringed with black, anterior row recurved, eyes subequal, a.m.e. diurnal, touching, posterior row procurved, p.m.e. largest of the eight, angular, touching, lateral eyes subequal and touching; quadrangle higher than wide and wider behind than in front; clypeus about as high as quadrangle; mandibles pale, vertical; sternum pale, dark about margins, not quite as wide as long, tip very broad and continued between the fourth coxæ as a broad lobe, convex, with many dark hairs; abdomen pale, with a narrow transverse silvery band about the middle that is broken on median line, oval, base high and extending over cephalothorax, a few short hairs on dorsum, venter pale gray; legs short and varying little in length, pale with rows of dark hairs; epigynum, area convex and slightly protruding from the venter, anterior margin very long, with area below very narrow, a broad median septum with dark areas each side.

Holotype, \& Alabama; Alexander City, 1-14 August 1944, (Nelson).

Theridiosoma nelsoni is much smaller than the two other species found in the United States. Theridiosoma radiosum McCook is found abundantly in the eastern part of the United 
States. The p.m.e. do not touch, the abdomen is covered with a brown net work and the epigynum has a large chitinized hood that protrudes from the venter and shows a triangular opening below. Theridiosoma argentatum Keyserling was described from an immature male from Georgia. The cephalothorax is $0.8 \mathrm{~mm}$. long and the abdomen, $2.2 \mathrm{~mm}$. long, with silvery spots and a brown net work, this is shown in the figure of the entire spider but the figure of the eyes is undoubtedly wrong as the a.m.e. are the largest and neither the anterior or the posterior median eyes touch.

Theridiosoma nelsoni is probably the species figured by Dr. Archer, 1941, p. 18, pl. 1, fig. 4, as Theridiosoma argentatum. He describes it in life as "a minute spider - a red abdomen with a conspicuous transverse band across the middle. The red fades to greyish in alcohol." Unfortunately he gives no measurements but mentions several places in Alabama where it is found. The figure of the epigynum agrees fairly well with Theridiosoma nelsoni.

\section{FAMily Gnaphosid $Æ$}

Genus Sergiolus Simon 1891

Sergiolus meretrix Chamberlin

Figure 3

Sergiolus meretrix Chamberlin, 1922, p. 153. "̂ North Carolina; Raleigh."

Sergiolus meretrix Kaston, 1945, p. 4, figs. 13, 22-24.

Female. Length, $5.3 \mathrm{~mm}$., ceph. $2.5 \mathrm{~mm}$. long, $1.5 \mathrm{~mm}$. wide, abd. $3.0 \mathrm{~mm}$. long, $1.5 \mathrm{~mm}$. wide.

Cephalothorax yellow with scattered long dark hairs, moderately convex, anterior margin narrowed to about one-third greatest width, thoracic groove very short and faint at posterior third; eyes cover middle two-thirds of anterior margin, anterior row straight, eyes subequal and equidistant, a.m.e. diurnal, separated by about a diameter, posterior row longer than anterior row, recurved, eyes subequal, p.m.e. little nearer to p.l.e. than to each other; quadrangle narrower in front and higher than wide; clypeus narrow, about equals diameter of a.m.e.; mandibles yellow, with many long black bristles, vertical, coneshaped; labium yellow, longer than wide, tip pointed; maxilloe yellow, twice as long as labium, strongly impressed, tips trun- 
cate and black; sternum pale yellow with many black hairs, convex, three-fifths as wide as long, fourth coxæ separated by half a diameter; abdomen oval, black with three transverse bands of white hairs, the basal band widest and broken at the middle, the median and distal bands narrower and connected at the ends, venter black with a vague U-shaped stripe, spinnerets long, ventral pair widely separated; legs, 4-1-3-2, a darker yellow than the cephalothorax, no dark rings, very few spines, I and II tibiæ, dorsal, 0, ventral, 1 at tip, I and II metatarsi, dorsal, 0, ventral, 1 at base, III tibia with a dorsal median spine, IV tibia, no dorsal median spine; epigynum, area wider than long, a pair of transverse oval depressions with heavily chitinized margins, each with two pits, near the slender septum, one pit above the other.

Male. Length, $4.5 \mathrm{~mm}$., ceph. $2.2 \mathrm{~mm}$., abd. $2.3 \mathrm{~mm}$. (Type).

Cephalothorax more slender than in the female; eyes, mouth parts and sternum as in the female; abdomen has been rubbed so that the white hairs on the basal band and the middle of the median band have disappeared, as well as the black hairs that cover the rest of the dorsum, showing a wide distinct scutum from the base to the white band near the tip, the posterior margin truncate, venter gray with wide pale lateral stripes; legs, I pair missing, III tibia with a strong dorsal median spine, IV tibia, no dorsal median spine; palpus shorter than cephalothorax, patella and tibia about as long as the diameter of the joint, tibial apophysis as long as the diameter of tibia, narrowing rather abruptly with the margins of the distal half parallel, with a recurved hook at the tip.

Holotype, of North Carolina; Raleigh, (Brimley).

Allotype, \& Alabama; Alexander City, 1-14 August 1944, (Nelson).

Additional specimen, ô Alabama; Silver Hill, September 1945, (Nelson).

Sergiolus meretrix Chamberlin is separated from S. variegatus (Hentz), found in the same area, by the broader transverse bands of white hairs on the abdomen and by the secondary characters. In the male of $S$. meretrix the scutum almost covers the dorsum, the tibial apophysis of the palpus is more slender and the sides of the distal half are almost parallel; in S. variegatus the scutum covers about one-half the dorsum and the sides of the tibial apophysis are not parallel. The difference is as 
great between the females of the two species, in S. meretrix the median septum of the epigynum is very narrow and the depressed areas are elongate, while in $S$. variegatus the septum is much wider and the depressions are nearly circular. Unfortunately, the specimen of $S$. variegatus figured by Mr. Emerton, 1890 , pl. 4, fig. 1, probably lacks more than one moult of being adult.

\section{Family Clubionid $A$ e \\ Genus Clubiona Latreille 1804 \\ Clubiona procteri Gertsch \\ Figure 9}

Clubiona procteri Gertsch, 1941, p. 10, figs. 17, 18. "요 Indian Town, Florida, 28 March 1938."

Female. Length, $4.5 \mathrm{~mm}$.

Cephalothorax typical; eyes seen from above, anterior row slightly recurved, eyes equidistant and subequal, posterior row slightly longer than anterior, eyes subequal, p.m.e. separated by fully two diameters and from p.l.e. by more than a diameter; quadrangle of median eyes narrower in front and wider than high; clypeus very narrow, less than a radius of a.m.e.; mandibles pale brown, geniculate, lower margin of fang groove with two teeth; epigynum, chitinized area longer than wide, posterior margin deeply notched, openings oblique, area between convex, spermatheca in anterior portion of area, separated by less than a diameter.

Allotype, \& Alabama; Silver Hill, July 1945 (Nelson). Additional specimens, of Alabama; Silver Hill, July 1945, (Nelson). ot North Carolina; Raleigh, 5-10 June 1943, (Brimley). ô Florida; Wabasco, 25 April 1944, (Nelson).

\section{Family Salticid}

Genus Habronattus F. O. P.-Cambridge 1901

Habronattus trimaculatus spec. nov.

Figure 11

Male. Length, $4.0 \mathrm{~mm}$., ceph. $2.1 \mathrm{~mm}$. long, $1.5 \mathrm{~mm}$. wide, abd. $2.0 \mathrm{~mm}$. long.

Cephalic plate black, with three pale spots, median spot largest, lateral spots elongate, posterior margin of the darkened area deeply emarginate, a posterior median black spearmark 
that reaches line of dorsal eyes, area each side bright yellow, a wide lateral dark spot each side, margins yellow, a fringe of long dark hairs above anterior eye row, widest between second pair of legs, sides almost parallel, cephalic portion high, thoracic falling abruptly on posterior two-fifths; eyes, anterior row straight by upper margins, a.l.e. about half a diameter of a.m.e., eyes of second row very small, and nearer first than third row, eyes of third row on margin, eye area occupies about one-third of carapace; quadrangle as wide behind as in front; abdomen black with a narrow pale basal band that extends on sides, a narrow median pale stripe which does not reach either end of abdomen, and two short oblique pale bars from the sides that extend only a short distance on the dorsum, a pair of widely separated white dots above the spinnerets, venter pale with three dark stripes; legs, 3-4-1-2, pale, with distal joints darker, third leg not modified and no fringes on first pair, spines, I pair, patella, prolateral, 1, tibia, ventral, 2 distal, followed by 1 prolateral, 1-1 retrolateral, metatarsus, ventral, 2-2, twice the diameter of the joint, II pair, spines same as on I pair but smaller, III pair, femur, ventral, at distal end, short prolateral and retrolateral rows of long stiff bristles, (may be trichobothria), no ventral median spine on tibia; palpus, femur pale, tibial apophysis a very slender black spur with tip constricted in an out turned hook, palpal organ typical, with inner process starting about the middle and ending about half way on the side, outer process staring on side above the tibial apophysis, following the contour of the cavity and ending at the tip, more slender than the inner process.

Holotype, of Florida; Sebastian, 1-7 April 1944, (Nelson).

The type and an immature male and female were collected at Sebastian, Florida in April by Mr. Nelson, probably by beating. All have the same markings. The species is related to Habronattus delectus (Peckham), known only from the type material of two males and a female found at Austin, Texas. It is separated from that species by the slightly larger size, darker legs, different spining of the first tibia and the tibial apophysis of the male palpus. Both have the three spots of white hairs in the eye area, a rather unusual character in this genus, but the posterior margin of the dark area between the dorsal eyes of $H$. delectus is transverse, while in $H$. trimaculatus it is deeply emarginate, and the tibial apophysis of delecus is broadly trun- 
cate. It is separated from $H$. tachypoda Chamberlin and Ivie, 1944, found at Briar Creek, near Sylvania, Georgia, by the three white spots on the ocular area, the lack of modified hairs and bristles on the first tarsus, and the tibal apophysis.

\section{Genus Marpissa C. Koch 1846 \\ Marpissa rupicola (Hentz)}

Figure 2

Attus rupicola Hentz, 1846, p. 357, pl. 21, fig. 14; reprint, 1875, p. 61, pl. 8, fig. 14. "o Alabama, September."

Female. Length, $10.5 \mathrm{~mm}$., ceph. $4.5 \mathrm{~mm}$. long, $3.5 \mathrm{~mm}$. wide, abd. $6.0 \mathrm{~mm}$. long, $3.5 \mathrm{~mm}$. wide.

Cephalothorax darkest about the eyes, two converging dark stripes from p.m.e. to posterior margin, with area between pale, quite flat, sides rounded, widest between second and third coxæ, thoracic groove distinct; eyes, first row covers entire anterior margin, strongly recurved, a.m.e. almost touching and twice the diameter of a.l.e., eyes of second row slightly nearer first than third row, eyes of third row subequal with a.l.e., but convex; quadrangle same width in front as behind, a long bristle below each p.l.e.; clypeus about wanting below a.m.e.; mandibles brown, with many long white hairs, vertical, not swollen, fang groove short, upper margin with two teeth, one nearer base of fang larger, lower margin with one tooth, fang short with a thick base; labium more than twice as long as wide; maxillice brown, almost twice as long as labium, tip widened; sternum about two-thirds as wide as long, narrower than labium at anterior end and ending in a rounded point in front of the fourth coxæ, widest between second and third coxæ; abdomen oval, quite hairy, dorsum flat, with a pale median stripe less than one-third the width of the abdomen, the pale stripe abruptly widened before the middle, the distal half bordered by dark stripes, a pair of small white dots above the spinnerets, sides mottled with dark, venter pale with dark dots; legs, 4-3-1-2, anterior pairs slightly enlarged, pale with ends of joints darker, spines, I pair, patella, 1 small prolateral, tibia, dorsal, 0 , ventral, 2-2-2, distal, median and basal, spines of prolateral row larger, prolateral, 1-1, retrolateral, 0 , metatarsus, dorsal, 0 , ventral, 2-2, lateral, 0, II pair same as I pair, posterior pairs with many spines; epigynum large, chitinized area longer than 
wide, a strongly chitinized excavate lateral openings on anterior half, a median raised ridge on posterior half sloping to depression on each side, the depressions separated by about a diameter.

Neotype, + Alabama; Silver Hill, July 1945, (Nelson).

Hentz had both male and female of this species but he figures the female only. He states that it was found in cavites of limestone rocks on the margin of a river and describes it as rufous and hairy. The figure shows the median pale stripe on the dorsum much narrower than in undata, (familiarius Hentz), found about houses. Mr. Peckham examined the specimens identified by Mr. Banks as rupicola from Ithaca, New York and Falls Church, Virginia, and found them to be only color varieties of undata. On examining these specimens, the epigynum proves to be the typical undata. It was Mr. Banks who first recognized this specimen as rupicola Hentz.

Marpissa melanura F. O. P.-Cambridge described from a female from Guatemala City, (Biol. Centr.-Amer., 1901, 2 : 251, pl. 22, fig. 7), also has excavations on the sides of the epigynum but the pale median stripe on the dorsum is quite broad and it has no indications of the pale cross bars near the spinnerets. This species has been placed by Peckham as a synonym of M. californica (Peckham).

\section{REFERENCES}

Bishop, Sherman C.

1924. A Revision of the Pisauridæ of the United States. Bull. N. Y. State Mus., Albany, 252, pp. 1-63, pls. 1-37.

Bryant, Elizabeth B.

1933. New and Little Known Spiders from the United States. Bull. Mus. Comp. Zool., Harvard, 74, pp. 171-193, pls. $1-4$.

Cambridge, O. P.-

1889-1902. Arachnida-Araneidæ, 1, pp. XV+317, 39 pls. In Biologia Centrali-Americana.

Chamberlin, Ralph V.

1922. The North American Spiders of the Family Gnaphosidæ. Proc. Biol. Soc. Washington, 35, pp. 145-172.

1929. On Three New Spiders of the Genus Oxyopes. (Araneina). Ent. News, 40, pp. 17-20. 
Emerton, J. H.

1924. New Spiders from Southern New England. Psyche, 31, pp. 140-145, text figs.

Gertsch, W. J.

1941. New American Spiders of the Family Clubionidæ. Amer. Mus. Novitaties, 1148, pp. 1-18, 6 pls.

Hentz, N. M.

1846. Descriptions and Figures of the Araneida of the United States. Jour. Boston Soc. Nat. Hist., 5, pp. 352-369, pls. 21, 22.

1847. (continuation). 5, pp. 444-478, pls. 23, 24, 30, 31.

1875. The Spiders of the United States. Occ. Pap. Boston Soc. Nat. Hist., 2, pp. XIII+171, pls. 1-21.

Kaston, B. J.

1945. New Spiders in the Group Dionycha with notes on other Species. Amer. Mus. Novitaties, 1290, pp. 1-18, pls. 1-7.

\section{Explanation of Plate 15}

Fig. 1. Thanatidius tenuis (Hentz), left palpus, ventral.

Fig. 2. Marpissa rupicola (Hentz), epigynum.

Fig. 3. Sergiolus meretrix Chamb., epigynum.

Fig. 4. Theridiosoma nelsoni spec. nov., epigynum.

Fig. 5. Oxyopes nelsoni spec. nov., tibia of left palpus, ventral.

Fig. 6. Thanatidius tenuis (Hentz), tibia of left palpus, lateral.

Fig. 7. Oxyopes nelsoni spec. nov., epigynum.

Fig. 8. Oxyopes aglossus Chamb., epigynum.

Fig. 9. Clubiona procteri Gertsch, epigynum.

Fig. 10. Oxyopes aglossus Chamb., tibia of left palpus, ventral.

Fig. 11. Habronattus trimaculatus spec. nov., left palpus, ventral. 


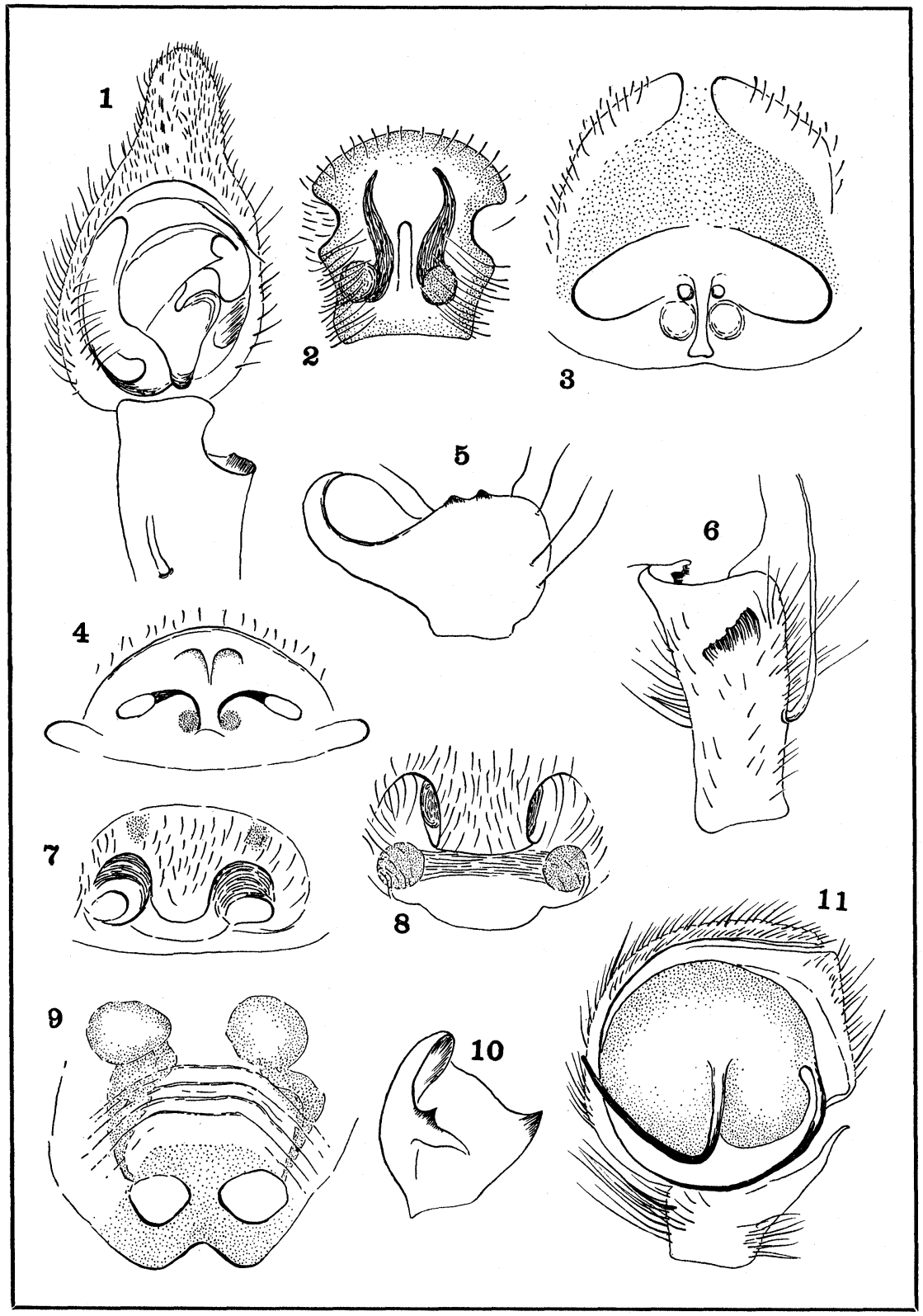

Bryant - Southern SpIDERS 

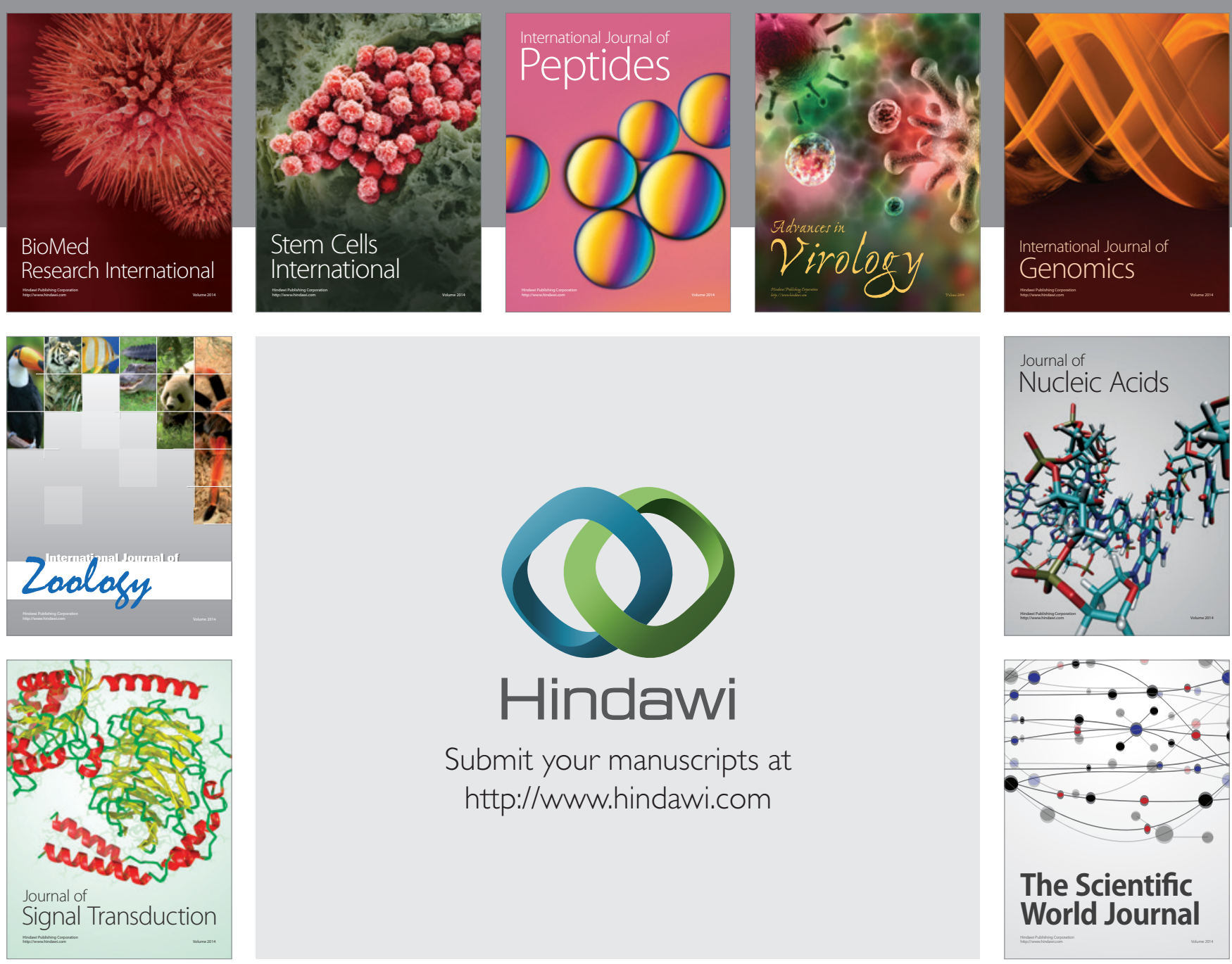

Submit your manuscripts at

http://www.hindawi.com
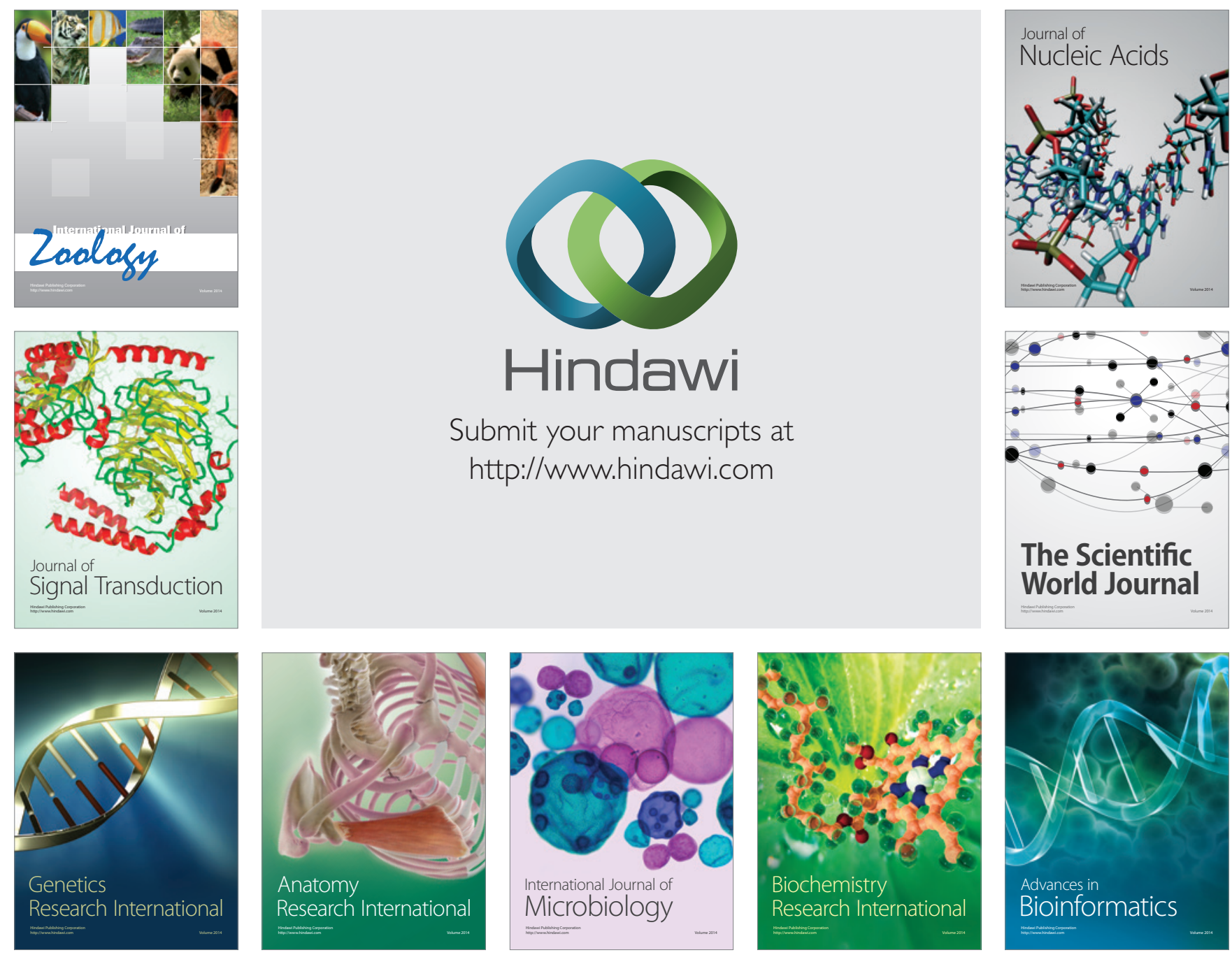

The Scientific World Journal
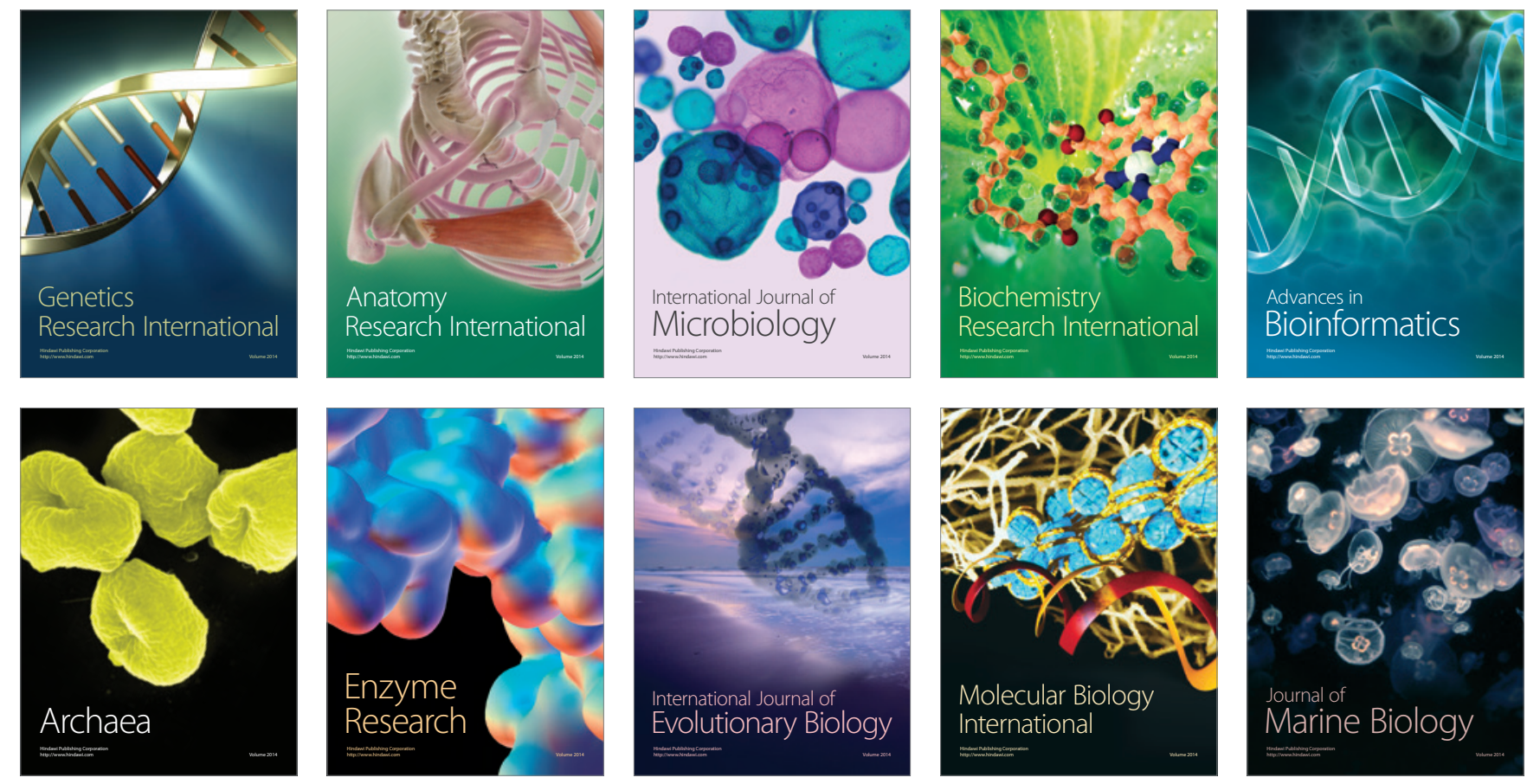